\title{
OBITUARY
}

\section{The late Professor R. F. A. Hoernlt}

IT was my privilege to be a colleague of the late R. F. A. Hoernle in two universities, and to be counted among his friends for nearly a quarter of a century. Though I was never a pupil of his, I did a little teaching for him in his Department at Armstrong College (now King's College), Newcastle-uponTyne, and was closely associated with him for more than ten years in the University of the Witwatersrand, Johannesburg.

The strongest philosophical influence upon Hoernlé was, I think, Bernard Bosanquet, whom he never tired of quoting. To the end he remained unconvinced by any of the attacks on the Idealist position which have been so notable a feature of philosophical thought in the present century. But nothing was more characteristic of Hoernle than his capacity for mastering the views of other men and restating them fairly, succinctly, and with an admirable lucidity, even when this was only a preliminary to a destructive criticism of them. He had a more orderly mind than most other men I have met in life, and I think it was this more than any other quality in him which made him so impressive a teacher.

To this virtue were added quite unusual powers of work and great courage. The longer he lived the busier he got, until latterly he was doing the work of two or three men of ordinary capacity; indeed, doing more than a man even of his capacity could keep up. In addition to his Department, he had innumerable duties in connection with the Race Relations Institute (of which for a time he was Chairman), an institute primarily devoted to the interests of the Native and Coloured population of South Africa; and, at any rate from the year 1940, he was giving many hours a week to Army Education. When causes like these had taken him by the heart, nothing and nobody could stop him from overworking himself for them. And yet, however tired he might be, his mind always seemed to remain as incisive as ever. I have heard many lecturers and public-speakers inside and outside universities; but I have never heard anyone who could surpass Hoernlé in clarity of exposition, whether the topic was one of his own choosing or not, and in seeing the other man's point of view. He spoke his mind-no one more emphatically-whether the result was palatable to his hearers or not. To do so in a country like South Africa can sometimes be startling, not to say explosive. But Hoernlé feared no man, however powerfully placed he might be. And this at least was certain, that when Hoernlé had delivered himself on any question, national or parochial, metaphysical or academic, no one could remain in doubt concerning the opinions expressed; they were clear, orderly, and pointed.

That this often annoyed men of more confused minds has to be admitted. It is not flattering to a muddler to have his arguments arranged and restated for him better than he can do for himself. But the very annoyance that we all sometimes felt with Hoernlé was a tribute to his powers. And no one who knew him well ever doubted his forthright honesty of purpose at all times.

Hoernlé's first book was Studies in Contemporary Metaphysics (1920), which he followed up with Matter, Life, Mind and God (1923), and Idealism as a Philosophical Doctrine (1924). In 1939 he published a notable book on South 286 


\section{O B I T U A R Y}

African Native Policy and the Liberal Spirit, of which Chapter III, on Liberty, is a particularly impressive statement of the Liberal point of view. During the last ten years of his life this was the only book he had time to produce, though he was steadily accumulating material for what might have been one of his best, a book on the philosophy of science. In these years, however, he wrote a number of important articles, most of them in English, but at least one in German, and one or two in Afrikaans. Of these I may mention "Freedom in the Present-Day World," in Philosophy, Vol. X, I935; "Concerning Reason in Human Affairs," in Mind, Vol. XLV, N.S., 1936; "Would Plato have approved of the National-Socialist State?" in Philosophy, Vol. XIII, 1938, and 'Kant's Concept of the 'Intrinsic Worth' of every 'Rational Being" " in The Personalist, Vol. XXIV, I943.

Had Hoernlé been content to be a philosopher and little else, he might, and I feel sure would, have produced more books in the later years of his life. But he insisted on carrying his philosophy into the world of affairs, in which he had become one of the best known and most respected figures in South Africa. And the world of affairs is exacting. It allows a man too little time in his study. J. Y. T. Greig. 